Hannah Ewence

University of Chester

h.ewence@chester.ac.uk 


\title{
Belgian refugees in Cheshire: 'place' and the invisibility of the displaced
}

\begin{abstract}
The First World War centenary has invigorated research into the Belgian refugee presence, especially at the local level. However, as this article argues, the responses which Belgians elicited locally, as well as the 'quality' and longevity of the memory culture surrounding them, was intimately tethered to ideas about and experiences of 'place' during the war and after. Exiled Belgians were almost uniquely positioned to communicate the totality of war as well as stand as silent representatives of the trauma of displacement. Yet this case study of the North West county of Cheshire demonstrates how wartime tragedy with regional consequences, as well as a preoccupation with combatant internees and casualties, eclipsed the everyday reality and the post-war memory of the Belgians.
\end{abstract}

Key words: First World War, Belgian Refugees, Cheshire, Place, Memory

$* * * * * * * * * * *$

In the main cemetery of the small English city of Chester, two gravestones stand, somewhat inconspicuously, side by side, under the shadow of a large birch tree. The more prominent of the two headstones marks the grave of Constant Wauters, a young Belgian soldier who died whilst convalescing in the city. Beside him lies Marie Verbinnen, identified with the epithet: 'Belgian Refugee'. She was one of more than 250,000 Belgians who fled to Britain during the the First World War. This period represented the largest single influx of refugees in the country's history and has long been utilised as a glowing example of a national 'culture' of philanthropy and humanitarianism. ${ }^{1}$ Madame Verbinnen's connection to Britain, the city of Chester and its people also ran deep. Throughout the four long years of the First World War, 
she, together with her three daughters and two sons, made a home for themselves in the city, becoming well known among the small community of fellow Belgians and Cestrians alike as tireless campaigners and fundraisers, dedicated to the interests of refugees, civilians and combatants from their home country. ${ }^{2}$ Whilst many other refugees returned to the continent as soon as circumstances permitted - even, in some cases, when war still raged - Madame Verbinnen remained steadfastly in Chester. ${ }^{3}$ Given such loyalty, it is perhaps rather fitting that the city became her final resting place. Overcome by a failing heart, she died just a matter of weeks after the longed-for Armistice was signed. Yet despite this 'staying power', as Peter Fryer might term it, and her relative prominence, Madame Verbinnen's death went un-noted in the local press. ${ }^{4}$ This was a sign of things to come. As the war receded, so too did public memory of her; a 'vanishing act' in keeping with the amnesia which also surrounds the history and memory of the two thousand or so other refugees who made their home in the North West county of Cheshire. ${ }^{5}$ After Verbinnen's surviving family had returned to Belgium, her grave lay untended and forgotten for almost a century. ${ }^{6}$

This article explores this phenomenon, asking what factors specific to the exiled Belgian community's status as 'refugees', and what factors specific to 'place' and locality, allowed and enabled Belgian incomers to Cheshire to increasingly recede from view during the war years, continuing their slide into oblivion after the war's conclusion. Within the context of war, refugees have, historically (as today), been almost uniquely placed to communicate the parallel tragedies of conflict and displacement. As civilians, their experiences can bridge the gulf between combatant trauma and domestic misreckoning of the magnitude of suffering behind the lines. Paying adequate attention to their history is thus a vital part of the jigsaw in piecing together the oft-fragmented understanding of home front perceptions of war, the avenues through which images and realities of conflict are constructed and communicated, and 
the multiple ways in which domestic populations demonstrate support for, or expressed fatigue with, distant wars.

Sadly, however, the considerable 'value' integral to refugee experience is all too frequently overlooked. Tony Kushner has argued that it is the fate of the refugee to be forgotten, whilst Peter Gattrell and Philippe Nivet root this neglect in the very label of 'refugee', arguing that this alone can operate to de-individualise, even de-humanise. ${ }^{7}$ As one Belgian quoted by them intonated: 'One was always a refugee - that's the name one was given, a sort of nickname (sobriquet). One was left with nothing, ruined, and that's how people carried on talking about the "refugee". We weren't real people any more." 8 As this article will demonstrate, the bureaucratisation of the Belgian influx by national government in the early stages of the war set the tone for how local administrators in Cheshire treated the refugee community, rapidly robbing them of identity and agency. So too, it will suggest, did the growing presence of enemy aliens and German POWs in the county, as well as the localised nature of catastrophes such as the sinking of the Lusitania, eclipse and erase the sympathy and attention that Belgians scattered throughout Cheshire had briefly enjoyed. These factors poisoned the fledgling roots of Belgian presence and, more particularly, the memory of that presence meaning that, whilst narratives of valour reinvigorated remembrance practices relating to combatants (including Belgians), refugees with links to Cheshire have not been so fortunate.

This neglect of Belgian refugees within histories of the First World War is an unfortunate historiographical trend. Until the recent rash of attention bequeathed to the Belgian refugee episode, largely as a consequence of the First World War centenary commemorations, the forced migration and exile of two million Belgians from 1914 typically elicited not more than a paragraph, frequently only a footnote, in histories of the conflict. ${ }^{9}$ Ironically, given the somewhat clinical approach of the authorities in Cheshire to the needs of the refugee community, it has been the field of local studies that has lavished the greatest care and attention 
upon this previously marginalised past. ${ }^{10}$ Place, but more specifically, the constructed idea of place has been shown to matter for, firstly, determining the type of response that refugees received as well as, secondly, dictating the 'quality' and longevity of the memory which emerged after their departure. Lorna Hughes has shown, for example, through a case study of Wales, that local agendas to raise Wales' cultural profile led prominent philanthropists to encourage Belgian artists and other creative types to locate there. Whilst, in reality, these efforts did not result in a greater proportion of artists and intelligentsia compared to other regions, the legacy of this policy has come to define local memory of the Belgian presence. ${ }^{11}$ Within other former host communities, a sense of the significance of their locale within the wider refugee story - the main port of entry at Folkestone being one such example - has provided a purpose for the preservation of public memory. ${ }^{12}$ The constructed place identity of Cheshire has not historically (and, in fact, typically still does not) celebrate the county as especially outward facing, a point of arrival or a space for diversity. Yet, as Driver and Samuel remind us, 'places are not so much singular points as constellations, the product of all sorts of social relations which cut across particular locations in a multiplicity of ways. ${ }^{13}$ Acknowledging that refugees helped to shape this dynamic process of place making, un-making and re-making even when only traces of them linger, makes this examination at the local level of critical importance; not just for the history of Cheshire or to right the wrong of Madame Verbinnen's marginalisation, but because it might also be another small step towards the writing of a more complete, more inclusive and more integrated history of the First World War.

\section{Cheshire in Context}

In 1914 the county of Cheshire, in North West England, was still, in the main, dominated by agriculture and its core industries of salt, chemicals, silk and cheese. ${ }^{14}$ Although a largely rural 
county, its borders encompassed the major urban centres of Birkenhead in the north west and Stockport in the east; incorporated within the metropolitan counties of Merseyside and Greater Manchester respectively after the border changes of 1974. This mixture of city and countryside, together with the county's proximity to the major ports on the Mersey and a shared border with Wales, resulted in a surprisingly diverse demographic. This included people hailing from elsewhere in the British Isles, a large contingent of Irish transient workers and long-established settlers, pockets of German merchants and shopkeepers, a thriving community of Russian and Eastern European Jews in Stockport, and Chinese lascars and labourers in Birkenhead. The outbreak of war was to bring yet more nationalities into the county. Soldiers from across Britain's vast global empire passed through Cheshire on their way to boats and trains to transport them to the front, or returned to the county for medical treatment, to convalesce or, in the case of an unfortunate few, made the county their final resting place. A sizable population of German POWs and enemy aliens also passed through Cheshire on their way to internment camps on the Isle of Man, or to the county's own camp at Handforth, a few miles outside of Wilmslow. Australian munitions workers lived in Chester whilst employed at HM Factory Queensferry, just over the border in Wales, and American soldiers were laid to rest in South Reddish, near Stockport, after falling victim to the influenza epidemic at the end of the war. ${ }^{15}$

Hence refugees arriving from Belgium in the early months of the war, although one of the earliest of the newcomers, nonetheless came to settle in a county not unfamiliar with cultural, linguistic and racial 'difference'. Even in the small city of Chester, the administrative heart of the county, working class districts such as Boughton, sandwiched between the railway and the River Dee, had long been home to a large community of mainly Catholic Irish who worshipped alongside the city's locally born Catholic population. The district also played host to a small community of Jewish shopkeepers and traders, whilst Chester itself was home to a number of wealthy Anglo-Jewish families who frequented a synagogue established in 1900 at 
White Friars, in the heart of the city. ${ }^{16}$ The smaller Cheshire towns of Crewe and Nantwich had also been used to continental Europeans contributing to the cultural tapestry of their public spaces. Brothers John and George Gronbach, both of German ancestry, built up successful pork butcher businesses in the neighbouring towns, occupying prominent positions in their respective town centres. ${ }^{17}$

The presence of Belgians in the county from September 1914 was, hence, initially a novelty and a source of early curiosity but caused few lasting cultural shockwaves. This was no doubt in part thanks to the ethnic and religious profile of the Belgians themselves: Christian European neighbours who spoke French or the much less familiar Dutch. Their distinctiveness was, therefore, evident linguistically but, in broadly cultural terms, this was not a 'difference' of insurmountable proportions. Demographically, however, the 'types' of refugees arriving in the county during the first months of the war was far more mixed. The Chester Courant declared a party from Antwerp arriving in the south of the county in September 1914 to be from the 'upper working-class and business section of the community', although this was an assumption based upon the 'good clothes' that they were observed to be wearing. ${ }^{18}$ More pointed enquires were made of the arrivals from Mechelen in Chester the following month, who gave their occupations from within various trades such as shoemaking and stonemasonry. ${ }^{19}$ By the end of the autumn, a growing number of wounded Belgian soldiers joined these groups of working class Dutch-speaking urbanites. So too did a member of the French-speaking Belgian aristocracy come to make up their number. ${ }^{20}$

For French-speakers, the language barrier proved, in all likelihood, to be less of a hindrance than for those whose primary language was Dutch. Certainly, in some cases the press preferred to use the French name for places such as Mechelen/Malines, despite its firmly Flemish origins, thus unwittingly colluding in the Gallicisation of Belgian identity. These Francophone tendencies anticipated the communication difficulties that were to arise between 
the local population and the predominantly Flemish newcomers. This most certainly engendered anxiety amongst the refugees who were reported in the local press to have been 'frightened at the possibility of visiting England, on account of their inability to speak the language'. ${ }^{21}$ Similarly, for Cheshire locals, spirited welcomes were soon tempered by the realisation that few of the refugees could comprehend their kind words. A volunteer with the Red Cross Chester Division recalled racing into the city to purchase 'a Belgique dictionary to get in touch with them Belgiques' after an ambulance train of Belgian soldiers arrived in the city, suggesting that these types of practical difficulties had simply not been anticipated prior to the arrival of the Belgians. ${ }^{22}$ Hence, the origins, occupations, social class and even language of the refugees and wounded combatants arriving in Cheshire were far from formulaic or foreseen. Yet, local people seemed unperturbed by the challenges that overcoming these markers of difference posed.

One perceived aspect of the Belgians' cultural profile proved to be a favourable attribute during their stay in the county: their Roman Catholicism. Cheshire's sizable Catholic population and long-established provisions for worship meant that the new arrivals were frequently greeted as spiritual compatriots and the rightful benefactors of Catholic charity. ${ }^{23}$ Whilst not all refugees were Catholic, and certainly Catholicism was by no means the largest Christian denomination in Cheshire, the perception of a religious affinity or familiarity with Catholic culture and lifestyle acted to speed the Belgians' acculturation into local communities, further erasing signs of their distinctiveness. This was particularly important in the smaller Cheshire communities who received refugees. Crewe's early relief effort, for example, was led by its Ursuline convent, whose French order of nuns were well placed both spiritually and practically to commune with the Belgian Catholic families to whom it offered accommodation. $^{24}$ 
Common religious affiliations also helped to create a sense of a shared moral outrage at the plight of the refugees, directed primarily towards the main protagonists of the distant war. 'We sympathize with you deeply', the Mayor of Crewe rushed to assure arriving Belgians in October 1914. 'You have been face to face with difficulties, you have had a tyrant wading through the blood of slaughtered armies, and marching to the music of a nation's groans, and for that reason we trust your sojourn here will be a happy one. ${ }^{25}$ This conceptualisation of Germany as a 'brute' who had 'raped' and pillaged 'brave little Belgium' was a central component of nationwide wartime propaganda, playing an especially important role in generating support for the granting of asylum to Belgians in the early stages of the war. ${ }^{26}$ At county level, however, a perception of a commonality of Christian ethics was a particular feature of Cheshire's response to the refugees, further helping to cement the position of Belgians in the county as innocent 'victims' of German belligerence, and, therefore, 'deserving' recipients of philanthropic activity.

The earliest offer of hospitality towards beleaguered Belgians came in the very first days of the conflict from Sir John Brunner, a prominent Cheshire industrialist. The Times reported on 15 August 1914 that Brunner had already made arrangements with the Belgian minister 'to offer hospitality to the families of his friends in Brussels' urging others in Britain to do the same. ${ }^{27}$ His call for action was swiftly answered by philanthropically minded members of the aristocracy who, under the direction of Lady Lugard, lobbied the British government for the establishment of a scheme to offer asylum to Belgian women and children. From this, the War Refugees Committee (WRC) was born; a voluntary philanthropic body who set about their task by issuing an appeal in the national press for offers of material assistance, financial aid and hospitality for the incoming refugees. As the number of arrivals increased exponentially after the bombing of Malines in early September 1914, the government made their own offer of hospitality via the Local Government Board (LGB), at that time under the 
presidency of Herbert Samuel. From that point onwards, the complex, often laborious tasks involved with registering, transporting, accommodating and supporting a large refugee community were divided up between the LGB and the WRC. Whilst the LGB supervised arrivals at ports, provided accommodation in London and arranged for the refugees' onwards transportation, the WRC allocated refugees to the homes offered by the public. Once the refugees had been settled, local relief committees often took over responsibility for their welfare. ${ }^{28}$

A Ministry of Health report published after the war concluded that local relief committees numbered as many as 2,500 at the peak of the refugee influx. ${ }^{29}$ In early September 1914 , the LGB had sought to capitalise on the groundswell of public sympathy for the incoming Belgians, asking War Relief Committees already in existence to establish sub-committees to 'assist in providing hospitality and help for refugees' ${ }^{30}$ Cheshire was quick to respond to the call, broadening the remit of Committees across the county to take account of the growing refugee population accommodated locally. ${ }^{31}$ Yet, not all Cheshire communities were able to offer hospitality, however much they wished to be able to. Despite the extensive network of relief organisations in existence across the county, Cheshire was limited as to where it might receive and disperse refugees. Birkenhead and Wirral peninsula were prohibited from receiving refugees because they qualified under the Defence of the Realm Act as 'areas of a defended harbour'. ${ }^{32}$ Several of the larger towns in the county were also restricted zones requiring any alien, whether 'friendly' or otherwise, to register with the local police.

Despite these restrictions, Cheshire was, in various other ways, geographically well placed for the receipt and accommodation of refugees. The county benefitted from the efficient and extensive train service operated by the London and North Western Railway, at the time the largest railway company in Britain, which ran services between the capital and major urban centres in the northwest such as Manchester and Liverpool, as well as the Irish mail service to 
Holyhead. Major rail arteries ran through the county, stopping at virtually every town or village. Crewe, in the south of the county, served as an important railway junction. That said, lying at a distance of upwards of 150 miles from London and further still from the south coast ports, Cheshire was not as conveniently situated for the newly arriving refugees as some of the southern counties. Whilst railway travel was relatively fast, journeys by road could take a day or longer. The Chester Courant reported that refugees arriving in Congleton and Sandbach by road in mid-September 1914 had spent the night in Dulwich baths, South London, before commencing their journey to the northwest. They arrived in Sandbach at $7 \mathrm{pm} .{ }^{33}$

Nonetheless, during the course of the war, Cheshire was the fourth largest reception centre for Belgian refugees in the north of England, and the twelfth largest in England overall, registering, by November 1916, some 2,000 refugees. ${ }^{34}$ At its peak the numbers may have been higher still. The total calculated in 1916 does not allow for the reasonably high rate of return by this point in the war. For the purposes of offering accommodation and relief to Belgians arriving in Britain, Cheshire was divided into 44 districts, which, in turn, were managed by local subsidiary committees. Cheshire War Relief Committee, who oversaw this administrative network, operated out of Northgate Street, Chester. Their secretary, Reginald Potts, clerk of the peace for the county of Chester, served as the chief point of communication between national government bodies, local government, war relief committees and other local institutions. His job was, inevitably, busy, complex and, at times, deeply frustrating, requiring the careful management of the often competing demands and priorities of the various interested bodies. However, Potts seems not to have had any direct communication with the refugees themselves or, at least, there is no surviving record of it. Instead, the refugees emerged only indirectly in his copious correspondences as a faceless and largely nameless collective of 'Belgians'; indicative, perhaps, of a growing disinterest shown by local government and the 
local press in the refugee population once the initial excitement elicited by their arrival had subsided. $^{35}$

\section{A Receding Presence}

As the war dragged on through its first winter and spring, bureaucrats in Cheshire tackled the daunting challenge of accounting for all the Belgian refugees who had arrived in the county the previous autumn. This task was at the behest of the Registrar General at Somerset House in London who had been belatedly commissioned by the government to compile a complete register of all war refugees residing in the country. ${ }^{36}$ For Reginald Potts in Cheshire, there was considerable difficulty ascertaining precise numbers, not least because of an underlying confusion amongst officials as to whose responsibility it was to hold the original records of entry and settlement - if such things existed at all. According to T. T. S. de Jastrzebski, statistician for the Registrar General, the administrative maelstrom of the cataloguing process begun in their offices as a consequence of 'an overwhelming amount of work with a comparatively raw and insufficient staff, hampered by inadequate accommodation and faced continuously with new and impractical demands from more influential Committees and Commissions' ${ }^{37}$

This confusion was felt 'down the line' by the various receiving centres in the North West. In the first instance, Potts referred the matter to the Cheshire constabulary but, despite the requirement for all aliens resident in the county to register with the police, the constabulary were unable to furnish Potts with the records that he required. ${ }^{38}$ Thereafter followed a very protracted process of many months in which Potts attempted to extract the required information from the tangled web of independent relief committees operating across the county. ${ }^{39}$ His task was complicated still further by the entry into the fray of the Government Commission for 
Providing Occupation for Belgian Refugees in early 1915, who demanded an entirely separate return detailing the current employment status of all refugees. The request for the completion of yet more paperwork was not well received by some of the local committees. Northwich and District Belgian Refugee Committee openly complained to the clerk of the town council that 'these returns are getting very troublesome' 40 whilst others appeared to have ignored the request altogether. Despite the initial request having been issued by the Government Commission in early February 1915, Cheshire did not file its return until the end of May, having been chased by the Commission on several occasions, and even then the return remained incomplete. $^{41}$

Throughout this entire bureaucratic tangle, the refugees themselves remained curiously subsidiary to proceedings. Jastrzebski admitted in his report to the Ministry of Health in 1919 that the work of the Registrar General was 'mainly of an impersonal nature, and its aim throughout was to maintain that impersonality as far as possible' ${ }^{42}$ This attitude similarly dictated the approach in Cheshire. Few refugees were ever mentioned by name within the records, their identities obscured from view. Even the visit of Count Goblet D'Alviella, the Vice-President of the Belgian Senate, to the county at the end of June 1915, did little to bring the refugees, as individuals, into focus. In arranging the visit of the Count, they were referred to only as numbers. Hence, Nantwich confirmed that five male refugees were planning to cycle to Tarporley to be in attendance when the Count toured the town, whilst Knutsford wrote that refugees had been invited to be present during Goblet's visit but was unable to provide 'the number' ${ }^{43}$

As human interest stories go, the arrival of a sizable number of war-ravaged foreigners in the county, fresh from the war-torn villages and towns of the Western Front, was by no means an everyday occurrence. Certainly, much was made of the refugees' arrival in the early weeks and months of the war. As others have noted elsewhere, the refugees and their plight 
quickly came to symbolise the barbarity of the German war machine, operating to arouse support for the war, compassion for the refugees, as well as to inflame anti-German sentiment. ${ }^{44}$ So intensely sympathetic was the initial response that the Cheshire Observer ran a campaign to declare 5 December 'Belgium Day', arranging for the Belgian flag to fly from the mast board in the Town Hall square. ${ }^{45}$ Yet, within the year, interest had waned and the refugees featured but rarely in the pages of the local press, once again falling into the shadows. Belgium Day was not repeated the following year.

The growing disinterest shown towards the refugee community by the local press perhaps a sign of the 'success' of their efforts to integrate - needs to be seen in relation to, or even as a direct consequence of, the wider national and global context of the war. By the spring of 1915, events on the Front Line - the halting of Britain's advance at Neuve Chapelle, the horrors of German gas warfare at the second battle of Ypres, and the launch of the Gallipoli campaign on the Eastern Front - filled the pages of the local and national press, meeting the insatiable demand for news from the battlefields, for speculation and commentary on the progress of the Allies, and for the tragic reportage of war casualties. In May 1915, the sinking of the passenger liner Lusitania by a German submarine, on route from New York to Liverpool, killing almost 1,200 passengers and crew, pushed the Belgian refugees even further from view. The localised dimension of the tragedy, with many of the ship's crew drawn from the port communities of Liverpool and Birkenhead, caused shockwaves across Cheshire. The Cheshire Observer, endeavouring to highlight that local link, reported on the individual cases of some victims, such as Thomas Hughes of Chester, a storekeeper on board 'the ill-fated ship', who, more than a week after the sinking, remained missing presumed dead. ${ }^{46}$ In Birkenhead, at least 27 seaman lost their lives, providing a premise for the outbreak of anti-German rioting in the city, directed against German pork-butcher shops and other commercial properties deemed to have a connection to the despised 'Hun'. As the Liverpool Echo reported, so great was 
Germany's 'foul crime' against local people that, when all was said and done, it could be pleaded in mitigation to account for the 'rowdyism' in Birkenhead and elsewhere. ${ }^{47}$ In other parts of the county, antagonism and xenophobia were coupled with displays of effusive sympathy for the victims. In the pages of the local press, Chester became a locus for much of that sympathy, positioned as it was as an important interchange and resting place for numerous survivors, many of whom travelled through the city on their way from Holyhead to various destinations across the country. ${ }^{48}$

As spring gave way to summer, the intensification of national policy towards enemy aliens, which followed in the wake of the sinking of Lusitania, further served to eclipse the once novel presence of the Belgians. One of Britain's largest internment camps at Handforth, in the east of the county, found its already existing population of 2,000 'enemy aliens' swollen by a further influx of civilians of German ancestry or nationality now deemed 'dangerous' enough to the national interest to warrant incarceration. The law courts also became increasingly busy with cases which directly reflected the souring local atmosphere towards civilians thought to have a German connection, however tenuous. In July 1915, Chester Assizes heard a case brought by Mr Schroder, an art teacher born in Hampstead to English parents and resident of Chester for 32 years who, nonetheless, had found himself the victim of slanderous rumours about his loyalty to Britain. The accused, a local butcher, was charged with paying Schroder one farthing in damages, although the judge refused Schroder's application for payment of his costs, deeming the case to have been 'unwise'. ${ }^{49}$ Reportage of the case commanded seven columns of print in the Cheshire Observer alone. Yet in the same month, the case of a Belgian refugee, Henry Guillaume Schafort, a resident of Chester imprisoned for stealing tools from a firm of mechanics, elicited a mere few hundred words ${ }^{50}$ Hence, whilst citizens deemed to harbour links to Germany became the subjects of unwelcome suspicion and press attention, the acts and actions of Belgian refugees elicited little public scrutiny. This was 
not a good will gesture on the part of the local press nor one which they were coerced to adopt. This stark contraction of press interest in the Belgians occurred even before the issuing of the so-called 'D' (Defence) Notices from July 1916 onwards which obliged the press to restrict the number of negative stories about Belgian refugees. ${ }^{51}$ Rather, the mundanity of news stories about local Belgians committing small-scale crime paled in comparison to the heinous 'criminality' of German action towards Britons on and off the battlefield. Moreover, minor infractions committed by Belgians lacked an obvious 'fit' with the 'war-hungry', often propaganda-driven agenda peddled by local newspapers.

This apparent disinterest in the Belgians, even at moments when their actions contravened and contradicted the largely positive image which had been constructed around them in the early months of the war, should, therefore be understood in large part as a direct consequence of the part that the 'Hun' now occupied in the local imagination. In late 1915, for example, even a case of domestic abuse between a Belgian couple, Augustor Lemmens and his young wife, prompted little comment from the Chester Courant, the main newspaper to cover the story. ${ }^{52}$ In contrast, the escape of six German POWs from incarceration near Chester in November 1917, brought forth rhetoric from the reporting journalist which framed the pursuit which followed in highly sensationalist language; indeed as a microcosm of the distant war. ${ }^{53}$ This seemingly indifferent treatment of the Belgians can be linked to their largely benign status as 'friendly' aliens; but so too did domestic altercations pose little match (as far as 'human interest' stories go) for prison-break style escapades by the hated enemy.

The increasing transience of the refugee population, compared to the greater permanence of other minorities in the county such as incarcerated Germans, similarly did little to re-energise interest in them as a newsworthy subject matter. In the case of the estranged Lemmens, for example, the conclusion of their case heralded their departure for London; an increasingly common route for the onward migration of the refugee population away from 
Cheshire by the mid-point of the war. In contrast, Germans incarcerated at Handforth and other smaller camps across the county languished at his Majesty’s pleasure well into $1919 .{ }^{54}$ Even for those refugees who remained in the county for longer duration, their initially elevated status as the point of contact between the distant front line and the home front was soon both obsolete (as the war moved on) and eclipsed by the influx of enemy prisoners and the returning wounded. Both of these groups, rather than the exiled Belgians, were now far better placed to communicate the horrors of the zones of conflict to communities on the home front.

By the third year of the conflict, Belgians in the county of Cheshire found themselves caught in a strange paradox. On the one hand, the threat of the German enemy 'at home' and on the distant front line overshadowed the novelty of their presence in the region. Yet, increased anxiety about foreign 'infiltration' served to shine the light of suspicion on the Belgian community in a manner which, prior to the intensification of the German threat, they had hitherto avoided. A short story in the Chester Chronicle illustrated this worrying development:

Tramp - Please, Mum, I'm a Belgian refugee

Lady: Are you? Mention a town in Belgium.

Tramp (cogitating a moment): I would, mum, but they have all been destroyed. ${ }^{55}$

The tone of this story - upon first impression typical of the sympathetic narrative constructed around Belgian suffering and loss - obscured an emerging ambivalence about not only the sincerity of the Belgians' claims for assistance but also their very identity as 'needy' refugees. The suspicion occasioned by the tramp's deflection of the lady's request for verification revealed a more insidious cynicism about the agenda of so-called 'refugees' resident in the 
county and country more broadly. As Catriona Pennell has suggested, as national paranoia grew about the presence of a 'fifth column' in Britain, Belgians found their formerly unimpeachable position as 'friendly aliens' increasingly challenged. In the more extreme cases, refugees were charged with providing a 'cover' for German spies. ${ }^{56}$ Government legislation restricting the movement of so-called 'aliens' - 'friendly' and 'enemy' alike - did little to alleviate the paranoia. For Belgians in Cheshire, this meant that seemingly innocent day trips to the nearby Welsh seaside resort of Llandudno (defined by DORA as a 'defended harbour') might bring the cloud of suspicion over them, resulting in an unwelcome summons and reprimand by the local magistrate ${ }^{57}$ Rising levels of intolerance for Belgians trying to recapture something of the 'normality' of everyday life thus illuminated just how thin was the veneer of hospitality extended to refugees by their British hosts.

This shift in attitude might also account, in part, for the tumbling levels of financial and material assistance offered to the refugee community by 1916 . Whilst apathy and preoccupation with personal loss no doubt played their part, suspicions surrounding 'foreigners' may also have fuelled declining subscriptions and the repositioning of Belgians from the foreground to the background of local consciousness. As press stories referencing Belgians as individuals declined, the reporting of funding pledged and raised for beleaguered Belgians on the continent and in Britain also fell sharply. However, pleas from local philanthropic organisations for greater support for the Belgian Relief Fund grew. ${ }^{58}$ Nonetheless, the refugees themselves receded further and further from view.

This growing apathy towards the refugee population was as much about geography as it was about developments emanating from the politics of war. Cheshire's particular geographical characteristics as a largely rural county with land and sea borders, port towns and cities, and restricted zones, impeded the establishment of any single sizable refugee settlement. The largest congregation of refugees, according to the employment census that was undertaken 
in 1915, showed that Altrincham, Bowden and Hale in the east of the county on the fringes of Manchester, and Chester in the extreme west housed the largest number of refugees, although in neither instance did the number surpass 100. Male refugees in the county found employment in various industries, from skilled work in trades such as carpentry and furniture making to unskilled work as farm labourers or gardeners, whilst women took up jobs in domestic service or in the clothing and textile industry. Indeed, the positions filled by refugees ranged across almost 50 different job roles. This dispersion of the refugee population during the working day was replicated after hours, with Belgians living in at least 30 separate districts across the county. ${ }^{59}$ This demographic dilution encouraged integration with the local population and regional culture in a way that simply was not possible for much larger settlements of refugees elsewhere in the country. Larger Belgian communities - at Birtley in Tyne and Wear, at Twickenham in south London, and at the reception centre in Folkestone, Kent, for example remained conspicuous by their very numerousness as well as the creation of a clear cultural profile which population density occasioned. ${ }^{60}$ For regional settlements, such as those established in Cheshire however, the lack of population density helped to render Belgians increasingly invisible and, by extension, increasingly forgettable.

\section{Degrees of Forgetting}

The cooling of interest in the Belgian presence in the county - whatever reason lay behind it was particularly pronounced in the case of the refugee community. Belgian combatants, however, continued to elicit interest and attention from the local population and press even as the war dragged on. This, as the tragic realities of conflict were played out, often took the form of demonstrative displays of gratitude for the 'ultimate sacrifices' being made by both domestic and foreign soldiers. The death of Private Soldat Jean Francois Vermeulen in Stockport 
Infirmary in October 1914, for example, occasioned a Catholic funeral with full military honours and an elaborate burial at a local cemetery. ${ }^{61}$ Although the death of Vermeulen may have been the first but was certainly not the last of a Belgian combatant on British soil, public interest in and sympathy for the loss of wounded Belgians did not diminish even as the death toll rose. This was evident in the extravagant outpouring of emotion in response to the death of a second Belgian soldier, this time in Chester in early March 1915. Constant Wauters, a 26 year old Private within the Belgium Army to whom Madame Verbinnen would eventually become a neighbour in Overleigh Cemetery, died from meningitis, a complication of his wounds, at Richmond House auxiliary hospital overlooking the River Dee in Chester. He had been a resident of the city since arriving on a hospital train from France. His funeral was an event of no small significance for Chester. Conducted with full military honours, it brought Cestrians and Belgians together in a display of effusive patriotism and respect for a 'fallen hero'. After a requiem mass conducted by Father Loos, a Belgian priest in residence at St Werburgh's Catholic Church Chester, the coffin was draped with the Belgian flag and paraded through the streets to Overleigh. Hundreds of local people, Belgian refugees and convalescent Belgian soldiers from across the North West flocked to the city to walk behind it. ${ }^{62}$

Unhappily, however, Vermeulen and Wauters' death were not isolated cases for the Belgian community resident in the county. A matter of weeks prior Josef Detiege, a diamond cutter from Antwerp exiled in Sandbach in the south of Cheshire, took his own life. The Chester Courant reported that the deceased was depressed as a consequence of illness and the loss of all his worldly possessions and property in Antwerp. The court presiding over the inquest returned a verdict of 'suicide whilst temporarily insane' - a ruling typical of inquests investigating cases of suicide at that time. The coroner displayed considerable empathy for the plight of the refugee, extending his sympathies to Detiege's wife and daughter, whilst stressing that for 'the brave Belgians' the dual challenges of finding oneself 'in a strange country and 
these troublesome times would unhinge the strongest minds' ${ }^{63}$ However heartfelt these words, they found no direct translation into action. After this short report in the Chester press, Detiege disappeared from local consciousness. Whilst the local burial register indicates that he was buried in a Sandbach churchyard, no gravestone was ever erected and no record was kept of Detiege's final resting place. ${ }^{64}$ There is a raw contrast here between the public spectacle surrounding Vermeulen and Wauters' funeral, of lying to rest 'heroes' of the war who had died a noble death, and the quiet passing of Detiege.

Peter Gatrell has written about this stark disparity - even in death - between soldiers and refugees; the former offered plentiful opportunity to be 'lionized' whilst the latter enjoyed no such opportunities, often repositioned at the margins of public consciousness (as indeed was the case for Belgians in Cheshire) before fading from view altogether. ${ }^{65}$ The pitiful itineracy of Belgian refugees, transported between ports, reception centres, town halls, camps and homes, dependent upon charity and local goodwill, and the victims of suspicion about their loyalty to, intentions for and contributions towards their host communities, left them vulnerable to a culture of neglect within the otherwise dynamic arena of combatant veneration and commemoration. Even the most heartrending scenarios which befell refugees could fail to attract the same level of attention awarded to combatants. It took a battle of several years' duration by one Cheshire man to bring attention to the forgotten and unmarked graves of two Belgian boys who died in Northwich during the war. Frans Buyssens and Henri Joseph Borghys, both aged ten, died of peritonitis contracted not long after arriving in the county. The industrialist John Brunner, so outspoken about Britain's 'duty' to offer hospitality to fleeing Belgians, paid for the funerals although no marker was erected over the shared grave. It is possible that Brunner assumed that the boys' remains would be repatriated to Belgium at the war's conclusion hence negating the need for a permanent marker. ${ }^{66}$ This, however, was not the case. The boys' families returned to Belgium, but the boys did not. The grave laid forgotten 
until the activities of a local amateur historian drew attention to its presence. In November 2016 Alan Lowe finally realised his ambition for 'his boys' to receive a gravestone. Yet even in the heightened sensitivities of an age only too aware of the plight of refugees, the rhetoric used to make the case for elevating the boys into local remembrance practices relied upon their identity as children rather than as refugees. As Lowe explained to a local magazine, 'They were children, they were real, they deserve to be remembered just as much as any soldier who died in that dreadful war because they were just as much victims of its horrors as anyone. ${ }^{67}$

Even for lauded 'fallen heroes' however, public spectacle and physical markers offer no guarantee of remembrance. In the years after their deaths and the pageantry of their public funerals, Wauters and Vermeulen both slipped from local memory. Whilst Wauters was honoured with a prominent place in Chester's main cemetery and a mention on St Werburgh's commemorative plaque, Vermeulen laid buried in an unmarked grave for more than a century. ${ }^{68}$ Cheshire residents cannot be held solely to blame for this neglect. Even at a national level, there has been little will to commemorate the contribution of allied servicemen to the war effort. Whilst memorial sites exist which honour soldiers from across Britain's Commonwealth, these same sites exclude those, such as Belgian soldiers, who fall outside the colonial relationship, despite the 'debt' of sacrifice which Britain might be said to 'owe' them. ${ }^{69}$ Moreover, until the launch of the AHRC Heritage Lottery Funded Engagement Centres, there have been few attempts in Britain's First World War commemorative activities to localise and make that same 'debt' relevant and relatable to regional communities. ${ }^{70}$ Neither in the 100 or so years since the end of the war has there been a concerted effort at the local level - at least not in Cheshire - to excavate histories of the war on the home front which deviate from the conventional narrative of neighbourhood 'tommies' leaving loved ones behind to fight for King and Country. It is only with the arrival of the centenary that scraps of Constant Wauters' story have been unearthed once more; his etched name on the St Werburgh's plaque a prompt and a clue for a 
local history group to 'rediscover' him as a representative of a demographic largely forgotten. ${ }^{71}$ Private Vermeulen was located even more by chance thanks to the efforts of the Friends of Stockport Cemeteries, whose work to preserve the heritage of Willow Grove Cemetery in Reddish as the war's centenary arrived led them to focus their attentions on military graves. ${ }^{72}$

In both cases, it was the deceased Belgians' identity as combatants which led to their 'rediscovery' as well as dictating the tone of their commemoration. The Friends of Stockport Cemeteries placed Vermeulen's story at the very heart of their 2014 centennial commemorations as a gesture to 'honour' a soldier who 'gave his life'; ${ }^{73}$ adopting a narrative which allowed Vermeulen's life and death to conform with the hegemonic public discourses of patriotism, valour and victory that surrounds popular histories of the Great War. It is a consequence of this sentiment that both Vermeulen and Wauters' memory have now become requisitioned by Cheshire's local history and heritage groups as a symbol of sacrifice as well as an emblem of transnational cooperation. Although various initiatives to elevate the importance of these Belgian combatants' brief lives and deaths in Cheshire inadvertently also led to the 'rediscovery' of the refugee community housed in the vicinity, it was these fatalities through conflict which not only took priority in commemorative events but also shifted the locus of local memory work to include the refugee experience. ${ }^{74}$ In the meantime, Josef Deteige, Frans Buyssens and Henri Joseph Borghys still await a public sanctification of their memory that unapologetically acknowledges them first and foremost as refugees.

This reticence to commemorate and prioritise the presence, identity and contribution of refugees typified even the earliest initiatives to construct a local culture of remembrance in Cheshire. At Hyde in the east of Cheshire, for example, Belgian refugees - some of whom were skilled cabinet markers - took on the role of carving the wooden memorial plaques which held the names of the local war dead as an act to display their gratitude for the hospitality shown to them by local people. ${ }^{75}$ Through that act, Hyde's community of refugees made themselves 
intrinsic to the creation of a physical commemorative marker of the war, yet they themselves were never intended to be nor have they ever become the subject of local remembrance practices. This might, in part, be attributed to the rapidity with which refugees departed - or, in many cases, were made to depart - the county at the end of the war. The British Government's hurried, incentivised nationwide repatriation programme, launched in earnest as soon as hostilities ceased, reduced the Belgian refugee community in Britain to just a few thousand by $1920 .^{76}$ This process of return was helped considerably by many refugees' decision to selfrepatriate, in some cases whilst war still raged. Cheshire's population of refugees, probably numbering a little over two thousand at its peak, was, hence, steadily and then very rapidly depleted from 1916 onwards. This depletion in visibility was compounded by the absence of sites and spaces in Cheshire which reminded local residents of their now departed guests. Unlike the Belgian communities at Birtley in Tyneside, for example, refugees in Cheshire did not congregate around one particular building, site or location but were instead dispersed across the county. Buildings which served to accommodate refugees rarely served this purpose alone or, once the refugees departed, were quickly returned to serve their original use, therefore further obliterating the memory of the refugee presence. In some cases, buildings which once housed refugees have been demolished altogether and the sites redeveloped. ${ }^{77}$

As Europe entered a period of fragile peace, a determination to 'move on' from the horrors of the war also acted as a buffer against the introspection necessary to construct a culture of reflection and remembrance into which the now returned refugees might fit. Ironically, it was the return to a state of war which (albeit briefly) appeared to provide the space in which such reflection might occur. In Cheshire, the German invasion and occupation of Belgium in May 1940 caused one local newspaper to draw a parallel between the plight of Belgians now fleeing for their lives and their countrymen a generation or so before. Indeed, the Cheshire Observer declared itself adamant that the impending arrival of a new cohort of 
Belgians to the county would stir 'memories of 1914', going to the trouble of providing a brief account of the local relief effort for the benefit of those born since the war. ${ }^{78}$ However, press interest during the Second World War in the tragic simile of Belgian exile to Britain was fleeting in Cheshire at least, prompting no other public call for re-remembering.

Yet throughout the twentieth century in Cheshire (as no doubt elsewhere) fine interpersonal threads continued to reach back to the refugees of the first war, evident in both the marital unions made between Britons and Belgians and the enduring friendships of onetime refugees with their former hosts. ${ }^{79}$ The tapestry of personal memory created by such threads remains as yet unwoven into the cultural fabric of Cheshire's public narrative of remembrance of the Great War. In many cases, they remain undocumented and unrecorded, stories told within families but never passing beyond private memory into the shared space of the public sphere. There has been, until recently, no obvious platform nor a ready audience for the articulation of such memories or the declaration of British-Belgian heritage traceable back to that period. ${ }^{80}$ This is not an omission unique to Cheshire but, in that county it has been compounded by various factors: a public reticence to embrace a history of demographic diversity little in evidence today, especially after the loss of the county's large metropolitan centres; the absence of a single heritage organisation willing or able to throw resources into researching this history and a paucity of funding to the county's only Record Office which, until recently, left documents relating to this episode poorly catalogued. These factors have contributed to a culture of neglect which has kept Belgian refugees in the shadows of Cheshire's 'known' domestic history of the First World War.

The centenary of the First World War has occupied a prominent public position in British political and cultural life throughout its four year duration. Yet widespread awareness of the 
resultant civilian displacement across the European continent - perhaps as high as four million - remains conspicuous by its absence. Many of the popular narratives of conflict remain rigidly defined by the binaries 'Home' and 'Front'; the latter category still further limited by 'Western Front' ${ }^{81}$ There seems little room for what or who falls between: the transient, those on the move across borders, families and individuals who existed on the peripheries. They do not 'fit' easily into accounts of the victorious and the vanquished or reside firmly enough on one side or the other of the demarcation line between the horrors of the frontline and the anxious peace away from the battlefields. There has been, as a consequence, no place for refugees within national remembrances of war. Equally, local remembrance practices, as has been the case in Cheshire, have typically lacked both the will and the means to correct this oversight. Refugee populations in the regions were spread thin, stayed for relatively short periods, left little physical trace and, even as potentially newsworthy subject matter, paled into insignificance as time went on when compared to the German 'menace'. Excavating such histories, therefore, is fraught with challenges, whilst making the case for all but the most perfunctory of commemorative activities marking their presence is a difficult idea to 'sell' to popular audiences who remain enamoured with honouring combatant sacrifice and home front suffering.

Yet, through their state of being 'in transit', immigrants, refugees and other displaced persons were, during the war years, one of the few groups who were able to communicate a sense of the totality of war to populations behind the frontline. They provided a link between 'here' and 'over there' whilst, through their very presence, signifying the destructiveness of war. Even as their role as emissaries of war became eclipsed by the returning wounded and German POWs incarcerated locally, they remained silent representatives of the trauma of displacement, exile and (figurative, if not literal) homelessness faced by millions of civilians during the war years and after. Their history, then, is integral to the writing of a connected and 
hence complete history of this turbulent episode. Yet their marginalisation from popular memories of the conflict is telling. It suggests, perhaps, a world eager to move on from the disconcerting ruptures of wartime, keen to seek assurances, amidst a horribly fractured and unfamiliar world, by relocating and reasserting a sense of unity and identity - of recapturing a mythologised notion of 'who we were' before and 'who we can be again' - devoid of incongruous forces from 'outside'. But this marginalisation speaks also of the Belgian refugees themselves: their position as 'friend' rather than 'foe' within home front rhetoric; a subconscious appreciation of their cultural and racial congruity with the local population; their quiet assimilation into the surrounding society. All of this rendered them increasingly unremarkable to Cheshire society - but, within the turbulent history of refugee movements across the twentieth century, rather remarkable indeed.

\footnotetext{
1 Marwick, The Deluge, 82-3; Cahalan, Belgian refugee relief, 500.

2 'Ous Belgisch Column', Leigh Chronicle and Weekly District Advertiser, 20 November 1914, p. 2. See also 'Belgian Refugees. Arrival at Chester', Chester Courant, 21 October 1914, p. 6.

3 This was the case with Marie Hermans, a resident of Deeside Cottage, Eccleston on the outskirts of Chester, who returned to Holland in 1915. See Eccleston CPC Correspondence relating to Belgian war refugees, MayAug. 1915, ZRP14/36, Cheshire Records Office (CRO).

4 Fryer, Staying Power.

5 Obtaining precise numbers of Belgian refugees in most regions of Britain are notoriously difficult to come by thanks to the belated efforts of central government to record Belgians entering Britain in the first instance and the chaotic record-keeping practices of the Central Register of Belgian Refugees thereafter. Nonetheless, in a report filed after the war, the Central Register placed the number of Belgians in Cheshire in November 1916 at 2,000. See Central Register of Belgian Refugees, 1914-1919 Report, Appendix No. 5, Report of the Work Undertaken by the British Government in the Reception and Care of the Belgian Refugees, Ministry of Health, 1920 , p. 73. The census returns made at county level in spring 1915, recording levels and type of employment, were acknowledged by Cheshire's War Relief Committee to be woefully incomplete, giving the total number of employed and unemployed men, women and children across Cheshire as just 609. This admission makes the Central Register figures appear to be the more reliable of the two.

6 I am grateful to Ann Marie Curtis for many of these biographical details.

7 Kushner, Remembering Refugees; Gattrell and Nivet, "Refugees and exiles," 213.

8 De Schaepdrijver, Le Belgique, 104-5, quoted by Gattrell and Nivet, "Refugees and exiles," 213.

9 This figure has been suggested by Zuckerman, The Rape of Belgium, 85 .

10 Kushner, "Local Heroes"; Storr, Belgian Refugees in Lincolnshire and Hull; Jenkinson, "British Responses to Belgian Refugees".

11 Hughes, "Finding Belgian Refugees," 214-6.
} 
12 Fredo Franzoni's 'Landing of the Belgian Refugees' (bequeathed to the town of Folkestone in 1916), which occupies a prominent position in Folkestone Museum, is also emblematic of the official role that this history still plays here.

13 Driver and Samuel, "Rethinking the Idea of Place," vi.

14 Ingham, Cheshire.

15 These and other examples of Cheshire's wartime demographic diversity have been uncovered by the Diverse Narratives project hosted by the Department of History and Archaeology at the University of Chester. See www.diversenarratives.com

16 Jewish Chronicle, 24 August 1900, p. 16.

17 Kelly's Directory, 1914, p. 296; Cope's Cheshire Directory and Buyer's Guide, 1914, p. 112.

18 'Belgian Refugees', Chester Courant, 16 September 1914, p. 2.

19 'Belgian Refugees', Chester Courant, 21 October 1914, p. 6.

20 'Distinguished Belgian Lady', Chester Courant, 11 November 1914, p. 6.

21 'Belgian Refugees', 21 October 1914.

22 Imperial War Museum (IWM) Interview catalogue number 560, Oral History Sound Recording, IWM, (1975).

23 'Chester and Belgian Refugees: Local Catholics' Offer', Chester Courant, 16 September 1914, p. 7.

24 'Belgian Refugees in Crewe', Nantwich Guardian, 2 October 1914, p. 5.

25 Ibid.

26 Viscount Bryce Report of the Committee on Alleged German Outrages, (London, 1915), B. S. 18/28, British Library.

27 The Times, 15 August 1914, p. 4. See also Cahalan, Belgian refugee relief, 25.

28 Report of the Work Undertaken by the British Government in the Reception and Care of the Belgian

Refugees, Ministry of Health, 1920, pp. 3-4.

29 Ibid. p. 9.

30 Ibid.

31 'The Belgian Refugees: Appeal to Crewe People', Nantwich Guardian, 18 September 1914, p. 5; 'War

Relief Committee', Chester Chronicle, 31 October 1914, p. 6.

32 Defence of the Realm Consolidation Act, 27 November 1914, MUN 5/19/221/8, National Archives, (TNA).

33 'Belgian Refugees', Chester Courant, 16 September 1914, p. 2.

34 Central Register of Belgian Refugees Report, p. 73.

35 County of Chester War Relief Committee, CCJ/11/1-30, CRO.

36 Report of the Work Undertaken by the British Government, p. 8-9.

37 Central Register of Belgian Refugees, 1914-1919 Report, p. 59.

38 Letter from Reginald Potts to the Chief Constable of Cheshire, 6 February 1915; reply dated 9 February 1915, CCJ 11/26 (1), CRO

${ }^{39}$ Letter from H. A. Leggett, Government Commission for Providing Occupation for Belgian Refugees, to Reginald Potts, 27 May 1915 and related correspondence, CCJ 11/27 (1-2), CRO.

40 Correspondence between C. E Newell at Northwich and J. Arthur Cowley, clerk of the council, 21 May 1915, CCJ 11/27 (1-2), CRO.

41 See various; CCJ 11/26 (1) and CCJ 11/27 (1-2), CRO.

42 Central Register of Belgian Refugees, 1914-1919 Report, p. 58.

43 Correspondence from Nantwich Local District Committee to Reginald Potts, 23 June 1915; correspondence between H. Cliffe and Reginald Potts, 23 June 1915, CCJ 11/26 (1-2), CRO.

44 For example Jenkinson, "Soon gone, long forgotten," 101.

45 'Belgian Day', Cheshire Observer, 5 December 1914, p. 5.

46 'The Lusitania', Cheshire Observer, 15 May 1915, 10.

47 'Aftermath of Rioting', Liverpool Echo, 11 May 1915, p. 8.

48 'The Lusitania', Cheshire Observer.

49 'Internment of Aliens', Cheshire Observer, 10 July 1915, 9.

50 'Belgian sent to prison', Cheshire Observer, 17 July 1915, p. 8.

51 Jenkinson, "Soon gone, long forgotten," 106-7.

52 'Belgian and his wife. Case at Chester. British beer too strong', Chester Courant, 15 December 1915, p. 2.

53 'German Prisoners' Escape', Cheshire Observer, 17 November 1917, 7.

54 'Untitled' The Times, 15 November 1919, 4.

55 'A Good Story', Chester Chronicle, 4 December 1915, p. 2.

56 See Pennell, A Kingdom United, 137.

57 'Local Belgians in Trouble', Chester Chronicle, 11 November 1916, p. 7.

58 'Belgian Relief Fund', Nantwich Guardian, 16 July 1915, 5; 'Belgian Relief Fund', Nantwich Guardian, 24 March 1916, 5. 
59 Government Commission for Providing Occupation for Belgian Refugees, CCJ 11/27 (2), CRO. I am indebted to John Curtis and Andrew Pleass for transcribing the employment census returns.

60 Declercq and Baker, "The Pelabon Munitions works," 156-7.

61 'Dead Belgian Soldier: Military Funeral at Stockport', Manchester Evening News, 31 October 1914, p. 3.

62 'Belgian Soldier's death at Richmond House', Chester Courant, 17 March 1915, p. 2.

63 'Refugee's tragic death', Chester Courant, 10 March 1915, p. 5. See also 'Refugee's Suicide: Sad Case at Sandbach', Nantwich Guardian, 9 March 1915, p. 2.

64 'Sandbach St Mary's burial register', P56/6341/21, CRO.

65 Gatrell, A Whole Empire Walking, 2.

${ }^{66}$ Alan Lowe has reached this conclusion after conducting extensive research into the circumstances surrounding the boys' burial. Email correspondence between Alan Lowe and the author, 17 April 2018.

67 Lowe, "They are our sons now," 14. See also Alan Lowe's entry on the Diverse Narratives website https://diversenarratives.com/2016/11/28/aliens-in-mid-cheshire-the-story-of-the-belgian-refugees/

68 A screen wall naming Vermeulen and other war dead was placed in the cemetery in 2016. The Commonwealth War Graves Commission erected an individual headstone over the grave in 2018.

${ }^{69}$ Examples of memorial sites to Commonwealth soldiers include the Obelisk in honour of Indian troops who had convalesced in the vicinity of Barton-on-Sea, Hampshire, erected in 1914; the Chattri on the Downs at Patcham, to the Indian war dead and the Anzac memorial on Weymouth Seafront. The National Memorial Arboretum also now hosts a memorial to Sikh servicemen who served during the First World War, whilst a memorial to African and Caribbean servicemen and women was unveiled in Brixton in June 2017.

70 Supporting 'community engagement activities' has been a central objective of the AHRC centres. See http://www.ahrc.ac.uk/research/fundedthemesandprogrammes/worldwaroneanditslegacy/worldwaroneengageme ntcentres/ (accessed 16 March 2018).

71 See We Shall Remember Them for the published outcome of the St Werburgh's First World War Memorial Board project.

72 My thanks to Sheila Robins of the Friends of Stockport Cemeteries for these contextualising details.

73 Robins, "Private Soldat Jean Francois Vermeulen".

74 Research conducted by St Werburgh's Parish Great War Study Group, for example, expanded to investigate the presence of Belgian refugees in Chester after the 'discovery' of Wauters.

${ }^{75}$ Middleton, History of Hyde, 160. See also Hyde War Memorial Trust, www.hwmt.org/panels.htm (accessed 17 April 2018).

76 Ewence, "Bridging the Gap."

77 This was especially the case in and around Chester. I am grateful to Ann Marie Curtis for passing on information about sites on Westminster Road in Hoole; Handbridge in Chester and Deeside Cottage, Eccelston; all of which accommodated Belgians during the war but have since been substantially altered or demolished.

78 'As in 1914', Cheshire Observer, 1 June 1940, p.8.

79 An example of the enduring legacy of one wartime marriage between a Belgian refugee and a Cheshire native featured in the local press during the Second World War. See 'Belgian Refugees in Chester', Cheshire Observer, 25 May 1940, p. 8. A package of correspondence between the Hicksons of Barnton, Cheshire and their wartime neighbours the Melsens from Antwerp, passed to the author by a descendent of Annie Hickson, is no doubt indicative of many similar friendships which continued after the war between the hosts and the hosted. 80 In Cheshire, this platform has been provided in part by the Diverse Narratives project.

81 This was very much the ethos of the Imperial War Museum North's centenary exhibition 'From Street to Trench' which ran from April 2014 to May 2015, whilst the newly redesigned permanent First World War exhibition at IWM London still places a recreated trench at its centre.

\section{Bibliography}

Cahalan, Peter. Belgian refugee relief in England during the Great War. New York: Garland, 1982.

Declercq, Christophe, and Helen Baker. "The Pelabon Munitions works and the Belgian village on the Thames: community and forgetfulness in outer-metropolitan suburbs." Immigrants and Minorities 34 no. 2, (2016): 151-170. doi.org/10.1080/02619288.2016.1174585 
De Schaepdrijver, Sophie. Le Belgique et al Première Guerre mondiale. Frankfurt: Peter Lang, 2004.

Driver, Felix, and Raphael Samuel. "Rethinking the Idea of Place." History Workshop Journal 39 no. 1 (1995): v-vii.

Ewence, Hannah. "Bridging the Gap between 'War' and 'Peace': The Case of Belgian Refugees in Britain." In Minorities and the First World War: From War to Peace, edited by Hannah Ewence and Tim Grady, 89-113. London: Palgrave Macmillan, 2017.

Fryer, Peter. Staying Power: Black People in Britain since 1504. Atlantic Highlands, N. J: Humanities Press, 1984.

Gattrell, Peter and Nivet, Philippe. "Refugees and exiles." In The Cambridge History of the First World War: Civil Society volume III, edited by Jay Winter, 186-215. Cambridge: Cambridge University Press, 2014.

Gatrell, Peter. A Whole Empire Walking: Refugees in Russia During World War I. Paperback edn. Bloomington and Indianapolis: Indiana University Press, 2005.

Hughes, Lorna M. "Finding Belgian Refugees in Cymru1914.org." Immigrants and Minorities 34 no. 2 (2016): 210-231. doi.org/10.1080/02619288.2016.1171148

Ingham, Alfred. Cheshire: Its Traditions and History. Edinburgh: Pillans and Wilson, 1920.

Jenkinson, Jacqueline, ed. "British Responses to Belgian Refugees during the First World War: Special Issue," Immigrants and Minorities 34 no. 2 (2016).

Jenkinson, Jacqueline. "Soon gone, long forgotten: uncovering British responses to Belgian refugees during the First World War." Immigrants and Minorities 34 no. 2 (2016): 101-112. doi.org/10.1080/02619288.2016.1172308

Kushner, Tony. "Local Heroes: Belgian Refugees in Britain during the First World War." Immigrants and Minorities 18 no. 1 (1999): 1-18. doi.org/10.1080/02619288.1999.9974956

Kushner, Tony. Remembering Refugees: Then and Now. Manchester: Manchester University Press, 2006.

Lowe, Alan. "They are our sons now." Our Town: The Northwich Magazine 82 (September 2016): 12-14.

Marwick, Arthur. The Deluge: British Society and the First World War. London: Bodley Head, 1965.

Middleton, Thomas. History of Hyde and its Neighbourhood. Hyde: The Higham Press, 1932.

Pennell, Catriona. A Kingdom United: Popular responses to the outbreak of the First World War in Britain and Ireland. Oxford: Oxford University Press, 2012. 
Robins, Sheila. "Private Soldat Jean Francois Vermeulen," Diverse Narratives. Accessed December 21 2017. https://diversenarratives.com/2015/01/30/private-soldat-jean-francoisvermeulen/

Storr, Katherine. Belgian Refugees in Lincolnshire and Hull, 1914-1919. Carnforth: Your P.O.D, 2011.

We Shall Remember Them: Biographies of men associated with St Werburgh's who gave their lives during World War 1. Lancaster: Scotforth Books, 2015.

Winter, Jay. Remembering War: The Great War between Memory and History in the Twentieth Century. New Haven, CT: Yale University Press, 2006.

Zuckerman, Larry. The Rape of Belgium: The Untold Story of World War I. New York and London: New York University Press, 2004. 